\title{
Short communication: The water footprint of dairy products: Case study involving skim milk powder
}

\author{
B. G. Ridoutt, ${ }^{* 1}$ S. R. O. Williams, $†$ S. Baud,† S. Fraval, $†$ and N. Marks $†$ \\ ${ }^{*}$ CSIRO Sustainable Agriculture National Research Flagship, Clayton, Victoria 3169, Australia \\ †Department of Primary Industries, Ellinbank Centre, Victoria 3821, Australia
}

\begin{abstract}
In the context of global water scarcity and food security concerns, water footprints are emerging as an important sustainability indicator in the agriculture and food sectors. Using a recently developed life cycle assessment-based methodology that takes into account local water stress where operations occur, the normalized water footprints of milk products from South Gippsland, one of Australia's major dairy regions, were $14.4 \mathrm{~L} / \mathrm{kg}$ of total milk solids in whole milk (at farm gate) and $15.8 \mathrm{~L} / \mathrm{kg}$ of total milk solids in skim milk powder (delivered to export destination). These results demonstrate that dairy products can be produced with minimal potential to contribute to freshwater scarcity. However, not all dairy production systems are alike and the variability in water footprints between systems and products should be explored to obtain strategic insights that will enable the dairy sector to minimize its burden on freshwater systems from consumptive water use.
\end{abstract}

Key words: life cycle assessment, water footprint, virtual water, global water scarcity

Concerns about climate change, global water scarcity, and the challenge of meeting the dietary requirements of a world population increasing toward 9 billion inhabitants are causing many to question the sustainability of current food production systems, especially the role of meat and dairy products (Steinfeld et al., 2006; Baroni et al., 2007; Marlow et al., 2009). This is creating widespread demand for product life cycle-based sustainability indicators that can support sustainable patterns of production, consumption, and investment (Munasinghe, 2010). The leading example is carbon footprinting, which is becoming widely adopted by business and will become mainstream in many markets, being underpinned by greenhouse gas accounting and reporting standards (e.g., ISO 14067, www.iso.org; standard under development) and an increasing number of government-supported product labeling schemes

Received June 17, 2010.

Accepted August 10, 2010.

${ }^{1}$ Corresponding author: brad.ridoutt@csiro.au
(Guignard et al., 2009). In the main, the science of product carbon footprinting is well established, being consistent with the global warming potential impact category used in life cycle assessment (LCA), and applications in the dairy sector are many (Rotz et al., 2010).

In parallel with carbon footprinting, interest in water footprinting is also developing due to the growing awareness that freshwater has become a scarce and overexploited natural resource in many parts of the world, threatening widespread irreversible environmental change and harmful impacts on human well-being (Rockström et al., 2009; Ridoutt and Pfister, 2010b). Human water use increased 6 -fold over the course of the twentieth century, which is twice the rate of population growth and clearly unsustainable (UN Water, 2006). Some public surveys report that water is a higher global priority than climate change (Circle of Blue and Globescan, 2009). As such, there exists a clear recognition that the effects of human production systems and consumption patterns on freshwater resources must reduce in intensity.

However, compared with carbon footprinting, the science of water footprinting is less well developed. In the dairy sector, LCA studies have either excluded any consideration of water use at all or have included an inventory of water use in dairy farming and dairy product manufacturing without any subsequent assessment of environmental impact (Berlin, 2002; Eide, 2002; Hospido et al., 2003; Capper et al., 2009). Similarly, early attempts at quantifying the water footprints of dairy products, (e.g., 1,000 L/L of milk, $5,000 \mathrm{~L} / \mathrm{kg}$ of cheese; http://www.waterfootprint.org), building on the concept of virtual water, have reported volumes only. Such volumetric water footprints have been described as potentially misleading and confusing (Ridoutt et al., 2009) because they fail to take into consideration the type of water being used and the local water scarcity where processes occur. For example, the potential harm associated with consumption of so-called green water, derived from natural rainfall over agricultural lands, is not equivalent to so-called blue water withdrawn from surface and groundwater resources. 
Table 1. Characteristics of the skim milk powder (SMP) production system

\begin{tabular}{lc}
\hline Variable & Value \\
\hline Farming subsystem & \\
Average farm grazing area, ha & 159 \\
Average cropping area, ha & 98 \\
Average number of milkers, head & 232 \\
Annual milk production, L/head & 6,095 \\
Average fat content, \% & 4.2 \\
Average protein content, \% & 3.3 \\
Farm income from milk, \% & 85.2 \\
Electricity consumption, kWh/farm per year & 70,036 \\
Diesel consumption, L/farm per year & 6,750 \\
Fertilizer use, t/farm per year & 73 \\
Purchased hay, t/farm per year & 18 \\
Purchased grain, t/farm per year & 330 \\
Irrigation water use, ML/ha & 0 \\
Dairy shed water use, L/head per day & 35.6 \\
Drinking water requirements, L/head per day & \\
Lactating cow & 150 \\
Heifer <1 yr old & 50 \\
Heifer >1 yr old & 80 \\
Bull & 70 \\
Dairy factory subsystem & \\
Net water consumption, L/kg of SMP & -7.6 \\
Allocation to SMP, \% & 65 \\
\hline
\end{tabular}

Our research concerns the application of a revised water footprinting calculation method (Ridoutt and Pfister, 2010a) to assess the effect of consumptive water use in the production of skim milk powder. To our knowledge, this is the first application of LCA to assess the impact of consumptive water use in the dairy sector. Our purposes are to provide strategic insights relevant to improving the sustainability of the dairy industry and to produce case study evidence relevant to the harmonization of water footprint calculation methods through the International Organization for Standardization (Working Group 8 of ISO; TC207/SC5).

The case study involved the production of $1 \mathrm{~kg}$ of skim milk powder (maximum $1.5 \%$ fat; maximum $5 \%$ water; minimum $34 \%$ protein; all wt/wt) in the temperate South Gippsland region of Victoria, Australia (median annual rainfall of 1,198 $\mathrm{mm}$ ), as well as packaging and transportation to the destination port of Yokohama in Japan. The farming subsystem, which was a conventional pasture-based system supplemented by purchased hay and grain, was modeled using data for 6 farms located within the supply catchment of the dairy (Table 1). These data covered the 2008-2009 financial year, were independently collected as part of a larger government-sponsored farm benchmarking study (Gilmore et al., 2009), and included the major farm inputs, such as purchased feed, electricity, fuel, and fertilizers, as well as cattle numbers, milk production, and livestock sales. Minor inputs to dairy farming (e.g., business services, veterinary services, agricultural chemicals) were modeled using other farm survey data describing average farm expenditure per unit of milk production for Victorian dairy farms (ABARE, 2010). Water use in the production of these inputs to farming was calculated using environmental input-output data (Foran et al., 2005) and other LCA database sources. Water use associated with the production of capital goods, such as machinery and buildings, was excluded from the assessment. Where allocation between coproducts could not be avoided, an economic approach to allocation was used. Life cycle inventories for water use in the Australian livestock sector are not yet sufficiently developed to enable a systems expansion approach to allocation.

Data on water collected and used directly on farm for livestock and dairy shed operations and the management and use of dairy shed wastewater were sourced from a recent survey (Callinan, 2010) and from consultation with local farming experts. These data were used to quantify the change in drainage and stream flow as a result of on-farm collection and use of precipitation. The baseline situation was modeled using the generalized equation of Zhang et al. (2001) relating evapotranspiration (ET) to precipitation $(\mathrm{P})$ for grassed catchments [1]. The difference between $\mathrm{P}$ and ET was assumed to contribute to deep drainage and stream flow. The model was then rerun, taking into account the collection of runoff in farm dams, losses via evaporation from dams and effluent management ponds (20\%), and the return to pasture of irrigation water from the effluent management system and urine from roaming cattle:

$$
\mathrm{ET}=\left(\frac{1+0.5 \frac{1,100}{\mathrm{P}}}{1+0.5 \frac{1,100}{\mathrm{P}}+\frac{\mathrm{P}}{1,100}}\right) \mathrm{P} .
$$

The dairy factory subsystem was modeled using data provided by the plant engineer. This system included inputs of reticulated town water, the recovery of water from the evaporator, on-site wastewater treatment, selected water reuse, and the discharge to a local stream of freshwater, which is regarded by the local water management agency as an environmentally beneficial flow. The indirect water use associated with other important inputs to the dairy factory subsystem, such as packaging materials, electricity, and cleaning elements, were also considered, as well as the fuel use associated with road and sea transportation. In the dairy factory subsystem, a physicochemical approach to allocation between co-products was used (Feitz et al., 2007).

This approach to creating an inventory of consumptive freshwater use is consistent with the principle described 
by Ridoutt and Pfister (2010a) of taking into account the way the production system limits the availability of freshwater for the environment and other human uses. The use of green water per se does not contribute to water scarcity. Until it becomes blue water, green water does not contribute to environmental flows, which are needed for the health of freshwater ecosystems, nor is it accessible for other human uses. Green water is only accessible through the direct occupation of land. Therefore, in this dairy product case study, green water consumed through pasture evapotranspiration has not been included in the inventory. The pasture-based agricultural system produces more drainage and stream flow than the natural forested ecosystem it long ago replaced (Rost et al., 2008). In addition, emissions to freshwater from fertilizers, pesticides, and industrial processes were not included because the environmental impacts are generally considered under other LCA impact categories such as eutrophication and freshwater ecotoxicity.

For impact assessment, local characterization factors for freshwater consumption were taken from the Water Stress Index (WSI) of Pfister et al. (2009). The average Australian WSI was used in relation to farm and industrial inputs where the location of production was uncertain. To calculate the water footprint, each instance of consumptive water use was multiplied by the relevant WSI and then summed across the product life cycle (from cradle to destination port). The product water footprint was normalized by dividing by the global average WSI and expressed in $\mathrm{H}_{2} \mathrm{O}$ equivalents $\left(\mathbf{H}_{2} \mathbf{O e}\right)$. This manner of expressing product water footprints is useful because it enables a decision maker to quantitatively compare the pressure exerted on freshwater systems through the consumption of a product (i.e., via indirect freshwater consumption) with an equivalent volume of direct freshwater use.

The production of $1 \mathrm{~L}$ of milk in South Gippsland, Australia (at the farm gate), was found to depend on $14.1 \mathrm{~L}$ of blue water consumption, with $83 \%$ occurring on-farm and the balance associated with the production of farm inputs. In contrast, the water footprint of this milk was $1.9 \mathrm{~L}$ of $\mathrm{H}_{2} \mathrm{Oe}$ per $\mathrm{L}$, meaning that the production of $1 \mathrm{~L}$ of milk in South Gippsland had an equivalent potential to contribute to freshwater scarcity (as defined by the WSI; Pfister et al., 2009) as the direct consumption of $1.9 \mathrm{~L}$ of water (at the global average WSI of 0.602). The water footprint was so small because the farms were located in a region of Australia with plentiful water and an extremely low WSI (0.013). Obviously, the water footprint would have been much higher if the farms were located in high-WSI locations, and especially if they depended on the use of irrigated pasture or significant amounts of purchased feed grown
Table 2. Volumetric blue water consumption $(\mathrm{L} / \mathrm{kg})$ and water footprint ( $\mathrm{L}$ of $\mathrm{H}_{2} \mathrm{O}$ equivalents $/ \mathrm{kg}$ ) for total solids in milk (at farm gate) produced in South Gippsland, Australia

\begin{tabular}{lcc}
\hline Item & $\begin{array}{c}\text { Blue water } \\
\text { consumption }\end{array}$ & $\begin{array}{c}\text { Water } \\
\text { footprint }\end{array}$ \\
\hline Total & 108 & 14.4 \\
Contribution (\% of total) & 0 & 0 \\
Irrigation & 10 & 2 \\
Dairy shed water use & 73 & 12 \\
Animal drinking water & 2 & 11 \\
Purchased feed & 15 & 76 \\
Other farm inputs & & \\
\hline
\end{tabular}

using irrigation. When expressed on a total milk solids (TMS) basis, the volumetric water use was $108 \mathrm{~L} / \mathrm{kg}$ of TMS and the water footprint was $14.4 \mathrm{~L}$ of $\mathrm{H}_{2} \mathrm{Oe} / \mathrm{kg}$ of TMS (Table 2).

Regarding the life cycle of skim milk powder, from cradle to export destination, more than $99 \%$ of blue water consumption was associated with the production of the milk (Table 3). Consumptive water use associated with transportation and packaging was minor and the process of converting whole milk into skim milk powder created a net surplus of freshwater returned to the local river system as an environmentally beneficial flow. The water footprint of skim milk powder was $15.8 \mathrm{~L}$ of $\mathrm{H}_{2} \mathrm{Oe}$ per $\mathrm{kg}$. The dairy factory subsystem made a small $(5 \%)$ positive contribution to the water footprint of the skim milk powder due to other inputs (such as electricity, cleaners), the manufacture of which consumed water in higher WSI locations than the dairy factory.

These results put the issue of consumptive water use associated with dairy products in an entirely different light compared with the volumetric water footprints mentioned earlier (e.g., 1,000 L/L of milk). We find it hard to see how volumetric water use could be a useful sustainability indicator for dairy products because the type of water used and the local water scarcity where processes occur are factors that must be taken into consideration if the environmental impacts of con-

Table 3. Volumetric blue water consumption $(\mathrm{L} / \mathrm{kg})$ and water footprint ( $\mathrm{L}$ of $\mathrm{H}_{2} \mathrm{O}$ equivalents $/ \mathrm{kg}$ ) for total solids in skim milk powder produced in South Gippsland, Australia, and transported to the destination port in Japan

\begin{tabular}{lcc}
\hline Item & $\begin{array}{c}\text { Blue water } \\
\text { consumption }\end{array}$ & $\begin{array}{c}\text { Water } \\
\text { footprint }\end{array}$ \\
\hline Total & 104 & 15.8 \\
Contribution (\% of total) & 19 & 81 \\
Inputs to farming & 87 & 12 \\
Water use on farm & $<1$ & $<1$ \\
Milk collection & -6 & 5 \\
Dairy product manufacturing & $<1$ & 2 \\
Packaging & $<1$ & $<1$ \\
Transport to destination &
\end{tabular}


sumptive water use are to be appropriately assessed. As such, strong caution is given against the public communication of volumetric water footprints. This case study has demonstrated that dairy products can be produced with minimal potential to contribute to freshwater scarcity (Tables 2 and 3). That said, not all dairy production systems are alike, and the variability in water footprints between systems and products should be explored in future research. This could lead to strategic insights that enable the dairy sector to reduce its burden on freshwater systems from consumptive water use. Such an approach is likely to be more effective in addressing global water scarcity and food security issues compared with simplistic recommendations to avoid livestock products altogether. Finally, it is important to note that water footprinting focuses on a single issue, namely freshwater scarcity and is not an indicator of overall environmental sustainability. Major strategic decisions should only be taken after considering all of the relevant environmental impacts as well as other social and economic concerns.

\section{ACKNOWLEDGMENTS}

We sincerely thank Karl Wild of Burra Foods (Korumburra, Australia), who assisted in data collection, as well as the farmers participating in the dairy farm monitor project. This study was funded by the Department of Primary Industries Victoria and CSIRO. The authors have exercised complete freedom in designing the research, interpreting the data, and making the decision to publish. Finally, we thank Jay Sellahewa (CSIRO, North Ryde, Australia) and Peerasak Sanguansri (CSIRO, Werribee, Australia), who reviewed the manuscript and made helpful suggestions.

\section{REFERENCES}

ABARE. 2010. http://www.abare.gov.au/ame/agsurf/agsurf.asp Accessed April 30, 2010.

Baroni, L., L. Cenci, M. Tettamanti, and M. Berati. 2007. Evaluating the environmental impact of various dietary patterns combined with different food production systems. Eur. J. Clin. Nutr. 61:279-286.

Berlin, J. 2002. Environmental life cycle assessment (LCA) of Swedish semi-hard cheese. Int. Dairy J. 12:939-953.

Callinan, L. 2010. Dairy Shed Water Use in Victoria. Department of Primary Industries Victoria, Melbourne, Australia.
Capper, J. L., R. A. Cady, and D. E. Bauman. 2009. The environmental impact of dairy production: 1944 compared with 2007. J. Anim. Sci. 87:2160-2167.

Circle of Blue and Globescan. 2009. Water Issues Research. http:// www.circleofblue.org/waternews/wpcontent/uploads/2009/08/ circle_of_blue_globescan.pdf Accessed May 3, 2010.

Eide, M. H. 2002. Life cycle assessment (LCA) of industrial milk production. Int. J. LCA 7:115-126.

Feitz, A. J., S. Lundie, G. Dennien, M. Morain, and M. Jones. 2007. Generation of an industry-specific physico-chemical allocation matrix. Int. J. LCA 12:109-117.

Foran, B., M. Lenzen, and C. Dey. 2005. Balancing Act: A Triple Bottom Line Analysis of the Australian Economy. CSIRO and University of Sydney, Australia.

Gilmore, D., M. Ryan, C. Swann, and D. Shambrook. 2009. Dairy Industry Farm Monitor Project. Department of Primary Industries Victoria, Melbourne, Australia.

Guignard, C., F. Verones, Y. Loerincik, and O. Jolliet. 2009. Environmental/ecological impact of the dairy sector. Bull. Int. Dairy Fed. 436. Int. Dairy Fed., Brussels, Belgium.

Hospido, A., M. T. Moreira, and G. Feijoo. 2003. Simplified life cycle assessment of Galician milk production. Int. Dairy J. 13:783796.

Marlow, H. J., W. K. Hayes, S. Soret, R. L. Carter, E. R. Schwab, and J. Sabaté. 2009. Diet and environment: does what you eat matter? Am. J. Clin. Nutr. 89(Suppl.):1699S-1703S.

Munasinghe, M. 2010. Can sustainable consumers and producers save the planet? J. Ind. Ecol. 14:4-6.

Pfister, S., A. Koehler, and S. Hellweg. 2009. Assessing the environmental impacts of freshwater consumption in LCA. Environ. Sci. Technol. 43:4098-4104.

Ridoutt, B. G., S. J. Eady, J. Sellahewa, L. Simons, and R. Bektash. 2009. Water footprinting at the product brand level: Case study and future challenges. J. Clean. Prod. 17:1228-1235.

Ridoutt, B. G., and S. Pfister. 2010a. A revised approach to water footprinting to make transparent the impacts of consumption and production on global freshwater scarcity. Glob. Environ. Change $20: 113-120$

Ridoutt, B. G., and S. Pfister. 2010b. Reducing humanity's water footprint. Environ. Sci. Technol. 44:6019-6021.

Rockström, J., W. Steffen, K. Noone, Å. Persson, F. S. Chapin, E. F. Lambin, T. M. Lenton, M. Scheffer, C. Folke, H. J. Schellnhuber, B. Nykvist, C. A. de Wit, T. Hughes, S. van der Leeuw, H. Rodhe, S. Sörlin, P. K. Snyder, R. Costanza, U. Svedin, M. Falkenmark, L. Karlberg, R. W. Corell, V. J. Fabry, J. Hansen, B. Walker, D. Liverman, K. Richardson, P. Cruzen, and J. A. Foley. 2009. A safe operating space for humanity. Nature 461:472-475.

Rost, S., D. Gerten, and U. Heyder. 2008. Human alterations of the terrestrial water cycle through land management. Adv. Geosci. 18:43-50.

Rotz, C. A., F. Montes, and D. S. Chianese. 2010. The carbon footprint of dairy production systems through partial life cycle assessment. J. Dairy Sci. 93:1266-1282.

Steinfeld, H., P. Gerber, T. Wassenaar, V. Castel, M. Rosales, and C. de Haan. 2006. Livestock's Long Shadow: Environmental Issues and Options. FAO, Rome, Italy.

UN Water. 2006. United Nations, New York, NY. http://www.un.org/ waterforlifedecade Accessed May 3, 2010.

Zhang, L., W. R. Dawes, and G. R. Walker. 2001. Response of mean annual evapotranspiration to vegetation changes at catchment scale. Water Resour. Res. 37:701-708. 